\title{
Hospital Shift Hours and Its Effect on Quality of Life among Nurses: A Comparative Study
}

\author{
Andina Prameswari' ${ }^{1}$, Ligina Ayudia1 ${ }^{1}$, Halimah Sya'diyah ${ }^{1}$, Aulia Iskandarsyah ${ }^{1}$
}

1 Departemen Psikologi Klinis, Fakultas Psikologi Universitas Padjadjaran

\begin{tabular}{|c|c|}
\hline Article Info & Abstract \\
\hline $\begin{array}{l}\text { Article History: } \\
\text { Submitted: Feb 24th }, 2021 \\
\text { Accepted: May } 25^{\text {th }}, 2021 \\
\text { Published: May } 31^{\text {st }}, 2021 \\
\text { Keywords: } \\
\text { Quality of Life; Nurses; } \\
\text { Mental health }\end{array}$ & $\begin{array}{l}\text { In organizing health services in hospitals, the nursing team is the frontline } \\
\text { for achieving service for } 24 \text { hours continuously, therefore in some division, } \\
\text { like ICU or ER, nurses work with shift hours. There is some evidence of shift } \\
\text { work's psychological and physiological effects that can influence nurses' } \\
\text { quality of life. This study aims to obtain an overview of the quality of life in } \\
\text { nurses who work into the shift and its comparison with non-shift. This study } \\
\text { was an online survey that involving nurses from hospital-based in Bandung. } \\
\text { The survey was distributed online, where participants who participated in } \\
\text { the survey had certain criteria. Data collection carried out with } \\
\text { questionnaires from WHOQOL-BREF, designed using a cross-sectional } \\
\text { comparative study model. Forty-five nurses were included in this study with } \\
\text { 82\% are woman, with 77,7\% work with shift and } 22,2 \% \text { no-shift. Overall, the } \\
\text { quality of life of nurses works in shift decreased in the physical domain. } \\
\text { Specifically, those who perceived themselves had physical pain. Even so, } \\
\text { they still perceived good quality of sleep. Nurses work in shift also perceived } \\
\text { negative emotion such as feeling blue, anxiety and depression. There were } \\
\text { two differences between nurse with shift work and non-shift work in quality } \\
\text { of life domains (physical, U=83,5, p-value=0,012) and (environment, U= } \\
102,5 \text {, p-value= 0,047). Physical pain, less free time to relax, and physical } \\
\text { activity such as exercising may influence the lower quality of life. Nurses } \\
\text { with shift work and nurses with non-shift work also found significantly } \\
\text { different in their overall health (U=84, p-value=0,008). It might be related to } \\
\text { how they perceived their health issue. }\end{array}$ \\
\hline
\end{tabular}

\section{PENDAHULUAN}

Secara profesi, perawat adalah tulang punggung dari rumah sakit yang dapat mempengaruhi kehidupan pasien [1]. Salah satu peran penting dari seorang perawat di dalam rumah sakit adalah sebagai penasihat bagi pasien. Karena perawat menghabiskan waktu dengan pasien lebih banyak dibandingkan dengan dokter dan terkadang ikut serta memberikan masukan kepada dokter terkait keunikan keadaan dari setiap pasiennya [2]. Sehingga dapat dikatakan perawat memiliki peran yang sangat besar dalam memberikan layanan kepada pasien.

Di Indonesia, berdasarkan data dari Kementerian Kesehatan, perawat

Corresponding author:

Andina Prameswari

andina18002@mail.unpad.ac.id

Media Keperawatan Indonesia, Vol 4 No 2, May 2021

e-ISSN: 2615-1669

ISSN: 2722-2802

DOI: $\underline{10.26714 / \mathrm{mki} .4 .2 .2021 .92-100}$ 
merupakan tenaga kesehatan yang memiliki jumlah paling besar (49\%) dibandingkan tenaga kesehatan yang lain dengan $70 \%$ jumlah perawat didominasi oleh wanita [3]. Walaupun begitu, jumlah tersebut masih belum bisa memenuhi rasio yang diharapkan secara nasional yaitu 180 perawat per 100.000 penduduk. Provinsi jawa barat merupakan provinsi yang memiliki ratio kedua terendah yaitu hanya terdapat 68.9 perawat per 100.000 penduduk [3]. Sehingga bisa disimpulkan bahwa pekerjaan sebagai perawat di Indonesia merupakan pekerjaan yang sangat dibutuhkan namun jumlah personilnya tidak dapat memenuhi kuota yang diharapkan.

Besarnya peran perawat di dalam pelayanan pasien menyebabkan rumah sakit memberlakukan shift kerja terutama pada bagian ER dan ICU. Namun sayangnya secara alami pemberlakukan shift kerja terutama dengan adanya shift malam bertentangan dengan ritme alami tidur manusia sehingga dapat memberikan dampak kesehatan akibat kelelahan [4]. Para perawat yang berkerja secara shift mengeluhkan adanya gangguan kelelahan dan juga obesitas [5]. Selain itu orang orang yang bekerja dalam shift juga mendapatkan konsekuensi negatif pada kehidupan sosial dan keluarganya [6] dan juga memilki kemungkinan yang lebih tinggi untuk mengalami gangguan psikologis seperti depresi [7]. Sehingga bisa disimpulkan bahwa pemberlakuan shift kerja terutama adanya shift malam memiliki dampak negatif bagi kehidupan perawat.

Potensi munculnya gangguan kesehatan dan dampak negatif lainnya dari jam kerja shift mempengaruhi kualitas hidup perawat [8]. World Health Organization mendefinisikan kualitas hidup sebagai persepsi individu terhadap posisinya didalam kehidupan dalam konteks budaya dan sistem nilai dimana dia hidup dan relasinya dengan tujuan serta ekspektasi, standar dan kekhawatiran yang ia miliki [9]. Kualitas hidup seorang perawat merupakan aspek yang sangat penting karena mempengaruhi kualitas layanan yang diberikan kepada pasien [10].

Penelitian mengenai kualitas hidup perawat di Indonesia menemukan bahwa lebih dari $50 \%$ perawat di Indonesia bagian barat mengalami burn out dan stress. Kondisi ini mempengaruhi kualitas hidup mereka [11]. Walaupun begitu penelitian tersebut tidak menjelaskan bagian tempat bekerja serta jam kerja dari perawat yang mengikuti penelitian tersebut. Sehingga penelitian ini memiliki tujuan untuk melihat bagaimana gambaran kualitas hidup perawat dengan jam kerja shift dilihat berdasarkan keempat aspek kualitas hidup menurut WHO. Apakah ada perbedaan antara kualitas hidup antara perawat dengan jam kerja shift dengan perawat dengan jam kerja non-shift.

\section{METODE}

Rancangan penelitian yang digunakan dalam penelitian ini adalah rancangan cross sectional dengan model pedekatan studi komparatif. Kuisioner penelitian didistribusikan secara online pada partisipan yang bersedia mengikuti penelitian dan memenuhi kriteria penelitian.

\section{Partisipan dan Pengambilan Data}

Partisipan yang mengikuti penelitian ini adalah perawat dengan kriteria: (1) bekerja dan berdomisili di Bandung (2) masa kerja penuh waktu selama lebih dari 3 bulan. Partisipan dijaring dengan cara memberikan informasi terkait penelitian ini kepada perawat representatif dari beberapa lokasi yang memiliki hubungan pertemanan dengan peneliti kemudian memintanya untuk menyebarkannya kepada rekan - rekan perawat ditempat mereka bekerja. Informasi untuk menarik partisipan berisi penjelasan mengenai penelitian yang dilakukan disertai tautan yang berisi kesediaan mengikuti penelitian, data demografi partisipan diikuti dengan instrumen penelitian. Partisipan yang 
bersedia untuk mengikuti penelitian langsung dapat mengisi google form berisi kesediaan mengikuti penelitian, data diri partisipan dan instrumen penelitian dari tautan yang dibagikan.

\section{Alat Ukur}

Kualitas hidup perawat akan diukur menggunakan WHOQOL-BREF yang dikembangkan oleh WHOQOL Group sebagai versi pendek dari WHOQOL-100. Versi bahasa Indonesia dari WHOQOL-BREF diterjemahkan oleh dr Ratna Mardiati dan Satya Joewana serta sudah divalidasi dan di uji reabilitasnya untuk bisa digunakan di Indonesia[12]. Alat ukur ini terdiri dari 26 aitem yang terdiri dari 2 pertanyaan yang mengukur persepsi individu terhadap kualitas hidup dan kesehatan secara umum dan 24 pertanyaan mengukur empat domain dari kualitas hidup yaitu: fisik, psikologis, relasi sosial dan lingkungan. Setiap aitem memiliki skor 1 - 5 menurut skala likert. Skor tersebut kemudian ditransformasi kedalam skala linier 1- 100 sesuai dengan panduan WHOQOL-BREF. Data demografi dikumpulkan dengan menggunakan kuisioner yang berisi: inisial nama, jenis kelamin, usia, suku, tempat tanggal lahir, domisili, bekerja di bagian apa, durasi kerja, pendidikan terakhir, status pernikahan dan jumlah anak.

\section{Analisa Data}

Data yang didapatkan dari 45 orang partisipan di analisa dengan menggunakan perangkat lunak Statistical Package for Social Sciences (SPSS) 21.0 version. Analisa data deskriptif dilakukan untuk melihat gambaran kualitas hidup perawat dengan jam kerja shift berdasarkan masing masing aitem pertanyaan dan gambaran kualitas hidup perawat dengan jam kerja shift dan non-shift berdasarkan rata - rata dari keempat domain kualitas hidup. Analisa Non-parametric digunakan untuk melihat perbandingan dari skor total dan masing - masing domain kualitas hidup serta persepsi perawat akan kualitas hidup dan kesehatan secara umum. Dilakukan uji normalitas menggunakan KolmogorovSmirnov test. Kemudian dilakukan uji beda untuk membandingkan skor masing masing domain kualitas hidup antara kelompok perawat shift dan non-shift, karena data tidak berdistribusi normal maka pengujian dilakukan menggunakan Mann Whitney test. Hasil pengukuran dianggap signifikan apabila $\mathrm{p}<0.05$. Distribusi frekuensi, dan presentase digunakan untuk memberikan gambaran data demografik partisipan melalui tabel.

\section{HASIL}

\section{Karakteristik Partisipan}

Partisipan dari penelitian ini terdiri dari 45 perawat, dengan jumlah perawat yang bekerja secara shift lebih banyak dibandingkan dengan perawat non-shift. Seperti yang bisa dilihat pada tabel 1, kelompok perawat dengan jam kerja shift berasal dari poli rawat inap, UGD, NICU, poli hemodialisa, dan ruang operasi. Dengan jumlah perawat dengan jam kerja shift terbanyak dari poli rawat inap (54\%). Sedangkan perawat dengan jam kerja nonshift berasal dari poliklinik (poli perawatan umum tanpa perawatan atau pasien menginap), perawat perusahaan, paramedis dan perawat di kesehatan publik. Dengan jumlah perawat dengan jam kerja non-shift paling banyak berasal dari poliklinik (60\%). Sehingga bisa disimpulkan bahwa perawat yang mengikuti penelitian ini cukup variatif karena berasal dari berbagai bagian.

Partisipan dalam penelitian ini paling banyak didominasi oleh perawat berjenis kelamin perempuan (82\%). Hal ini sesuai dengan data kementerian kesehatan yang menyatakan bahwa Sebagian besar perawat di Indonesia adalah wanita[3]. Tingkat pendidikan perawat yang menjadi partisipan dalam penelitian ini didominasi oleh perawat dengan tingkat pendidikan sarjana (51\%). Jika dilihat dari status pernikahan sebagian besar partisipan yang 
mengikuti penelitian ini berstatus sudah menikah (51\%).

Tabel 1

Data Demografi Partisipan

\begin{tabular}{|c|c|c|}
\hline Indikator & f & $\%$ \\
\hline \multicolumn{3}{|l|}{ Jenis Kelamin } \\
\hline Laki - laki & 8 & 17,8 \\
\hline Perempuan & 37 & 82 \\
\hline \multicolumn{3}{|l|}{ Etnis } \\
\hline Sunda & 31 & 68,9 \\
\hline Batak & 5 & 11,1 \\
\hline Jawa & 2 & 4,4 \\
\hline Ambon & 2 & 4,4 \\
\hline Minang & 1 & 2,2 \\
\hline \multicolumn{3}{|l|}{ Status Pernikahan } \\
\hline Menikah & 23 & 51,1 \\
\hline Lajang & 21 & 46,7 \\
\hline Bercerai & 1 & 2 \\
\hline \multicolumn{3}{|l|}{ Tingkat Pendidikan } \\
\hline Diploma & 13 & 28 \\
\hline Sarjana & 23 & 51 \\
\hline Magister & 6 & 13 \\
\hline \multicolumn{3}{|l|}{ Waktu Kerja } \\
\hline Shift & 35 & 77,7 \\
\hline Non-Shift & 10 & 22,2 \\
\hline \multicolumn{3}{|l|}{ Bangsal Perawat Shift } \\
\hline Rawat Inap & 19 & 54 \\
\hline UGD & 6 & 17 \\
\hline NICU & 5 & 14 \\
\hline HD & 3 & 8 \\
\hline Ruang Operasi & 2 & 5 \\
\hline \multicolumn{3}{|l|}{ Bangsal Perawat Non-Shift } \\
\hline Poliklinik & 6 & 60 \\
\hline Pusat kesehatan publik & 1 & 10 \\
\hline Perawat perusahaan & 2 & 20 \\
\hline Paramedis & 1 & 10 \\
\hline
\end{tabular}

\section{Perbandingan Kualitas Hidup Perawat Shift dan Non-Shift}

Kualitas hidup perawat dengan jam kerja shift dan non-shift dibandingkan berdasarkan pada keempat domain kualitas hidup dan juga persepsi akan kualitas hidup dan kesehatan umum secara keseluruhan pada WHOQOL BREF. Penelitian ini menemukan adanya beberapa perbedaan pada kualitas hidup antara perawat dengan jam kerja shift dan non-shift pada taraf kepercayaan 95\%. Hasil pengujian menggunakan Mann - Whitney nonparametric menemukan adanya perbedaan pada 2 dari 4 domain kualitas hidup yaitu pada domain fisik $(\mathrm{U}=83,50, p=0.012)$ dan domain lingkungan $(\mathrm{U}=102,50, p=0,047)$. Kedua kelompok perawat juga menunjukan perbedaan yang signifikan pada bagaimana mereka mempersepsikan kepuasan akan kesehatan secara umum $(\mathrm{U}=84,00, p=$ $0,008)$. Walaupun begitu, persepsi kedua kelompok perawat akan kualitas hidup secara keseluruhan tidak memiliki perbedaan $(\mathrm{U}=136,00, p=0,255)$.

Tabel 2

Perbandingan skor kualitas hidup berdasarkan domain WHOOQL BREF

\begin{tabular}{lccc}
\hline \multirow{2}{*}{ Indikator } & \multicolumn{2}{c}{ Kelompok } & \multirow{2}{*}{$\mathrm{p}$} \\
\cline { 2 - 3 } Fisik & Shift & Non-shift & \\
\hline Psikologis & $\begin{array}{c}53,16 \\
\pm 13,18)\end{array}$ & $\begin{array}{c}63,57 \\
( \pm 10,75)\end{array}$ & 0,012 \\
\hline Relasi sosial & $\begin{array}{c}69,99 \\
\pm 15,94)\end{array}$ & $\begin{array}{c}76,66 \\
( \pm 15,85)\end{array}$ & 0,329 \\
\hline Lingkungan & $\begin{array}{c}64,73 \\
\pm 18,56)\end{array}$ & $\begin{array}{c}74,16 \\
( \pm 14,93)\end{array}$ & 0,189 \\
\hline
\end{tabular}

\section{Kualitas Hidup Perawat Shift dan Non- Shift Berdasarkan WHOQOL-BREF}

Kualitas hidup perawat menurut WHOQOLBREF bisa dilihat dari skor total pada empat domain kualitas hidup yaitu domain fisik, domain psikologis, domain relasi sosial dan domain lingkungan. Pada kelompok perawat dengan jam kerja shift, domain psikologis memiliki skor rata - rata paling tinggi 69,99 dengan standar deviasi 15,94 diantara keempat dimensi kualitas hidup disusul dengan domain relasi sosial, dan domain lingkungan. Sedangkan skor rata rata terendah terdapat pada domain fisik 53,163 dengan standar deviasi 13,18. Pada kelompok perawat dengan jam kerja nonshift domain kualitas hidup dengan skor rata - rata tertinggi terdapat pada domain psikologis 76,66 dengan standar deviasi 15,85 disusul dengan domain lingkungan dan domainrelasi sosial. Skor rata - rata paling rendah pada kelompok perawat dengan jam kerja shift didapati pada domain fisik 63,57 dengan standar deviasi 10,75. Sehingga dapat disimpulkan bahwa kedua kelompok baik perawat dengan jam kerja shift dan jam kerja non-shift memiliki rata - 
rata kualitas hidup paling tinggi pada domain psikologis. Selain itu kedua kelompok memiliki rata - rata kualitas hidup paling rendah pada domain yang sama yaitu domain fisik. Secara keseluruhan, jika melihat dari rata - rata skor total dari masing - masing domain kualitas hidup, penelitian ini mendapati bahwa rata - rata skor keempat domain kualitas hidup perawat dengan jam kerja non-shift lebih tinggi dibandingkan dengan rata - rata skor keempat domain kualitas hidup perawat dengan jam kerja shift.

\section{Kualitas Hidup Perawat Dengan Jam Kerja Shift}

Penelitian ini menemukan sebagian besar perawat dengan jam kerja shift secara umum mempersepsikan kualitas hidup mereka baik. Selain itu, persepsi sebagian besar perawat dengan jam kerja shift terhadap kesehatan mereka secara umum cukup memuaskan.

Jika dilihat pada domain fisik, sebagian besar perawat dengan jam kerja shift menunjukan adanya gangguan fisik yang berdampak pada kehidupan sehari - hari mereka. Delapan belas orang perawat dengan jam kerja shift kadang - kadang mengalami rasa sakit fisik yang menghambat dalam menjalani aktivitas sehari - hari akibat rasa sakit. Walaupun begitu hanya 3 orang perawat yang memiliki kebutuhan untuk mendapatkan terapi medis untuk membantunya menjalani kehidupan sehari - hari. Temuan menarik dari penelitian ini adalah sebagian besar perawat dengan jam kerja shift cukup puas dengan kualitas tidur mereka.

Pada domain psikologis, hasil penelitian ini menemukan bahwa sebagian besar perawat memiliki persepsi yang baik terhadap keadaan psikologis mereka. Perawat dengan jam kerja shift merasa hidup yang mereka miliki merupakan kehidupan yang berarti. Selain itu, sebagian besar perawat seringkali bisa menikmati hidup yang mereka miliki. Perawat dengan jam kerja shift juga mampu untuk berkonsentrasi dengan baik. Temuan menarik dari domain psikologis adalah perawat dengan jam kerja shift terkadang memiliki perasaan negatif seperti kesepian, putus asa, cemas dan depresi.

Temuan menarik pada pada domain lingkungan bisa dilihat dari persepsi perawat dengan jam kerja shift akan waktu luang. Kebanyakan perawat menjawab mereka hanya kadang - kadang memiliki waktu luang untuk bersenang - senang dan melakukan rekreasi. Bahkan 4 orang perawat mengatakan bahwa mereka kurang memiliki kesempatan untuk bersenang senang. Selain itu, perawat dengan jam kerja shift merasa biasa saja terhadap akses yang mereka miliki pada layanan kesehatan.

Pada domain relasi sosial, sebagian besar perawat dengan jam kerja shift merasa cukup puas dengan hubungan sosial yang mereka miliki dengan orang lain. Perasaan cukup puas juga ditunjukan pada aspek dukungan yang diberikan oleh teman dan juga kehidupan seksual. Sehingga bisa disimpulkan bahwa sebagian besar perawat mempersepsikan relasi sosial mereka baik.

\section{PEMBAHASAN}

Kualitas hidup menurut WHO berfokus pada bagaimana individu mempersepsikan efek dari hambatan yang mereka alami terhadap kualitas hidupnya [9]. Kualitas hidup dalam penelitian ini diukur dengan menggunakan instrumen WHOQOL-BREF yang terdiri dari 4 domain yaitu fisik, psikologis, relasi sosial dan lingkungan. Selain itu dapat dilihat pula persepsi individu akan kesehatan dan kualitas hidupnya secara umum[13]. Berdasarkan hasil penelitian yang sudah disajikan sebelumnya maka terdapat beberapa hal yang akan dibahas. 


\section{Kualitas hidup perawat dengan jam kerja Shift}

Secara umum penelitian ini menunjukan bahwa kualitas hidup perawat dengan jam kerja shift menunjukan skor rata - rata paling rendah pada domain fisik, dilanjutkan dengan domain lingkungan, domain relasi sosial dan yang paling tinggi adalah domain psikologis. Domain fisik berkaitan dengan bagaimana perawat memandang keadaaan fisiknya terkait dengan rasa sakit yang dialami, energi yang dimiliki, kualitas tidur, mobilitas, aktifitas, pengobatan dan pekerjaan yang dimiliki[14]. Dari jawaban yang diberikan, terlihat bahwa perawat dengan jam kerja shift seringkali mengalami gangguan fisik yang akhirnya menghambat mereka dalam melakukan aktivitas sehari - hari. Walalupun begitu rasa sakit fisik yang mereka rasakan tidak membuat mereka memerlukan bantuan obat - obatan dan terapi medis untuk menjalankan kegiatan sehari - hari. Hasil ini sejalan dengan beberapa penelitian sebelumnya yang memperlihatkan bahwa jam kerja shift memiliki dampak menyebabkan gangguan kesehatan pada perawat [5,8]. Hal ini menegaskan bahwa rendahnya kualitas hidup pada domain fisik pada perawat yang memiliki jam kerja shift diakibatkan oleh munculnya gangguan fisik yang mengganggu mereka dalam berkegiatan sehari - hari.

Menariknya, penelitian ini mendapati bahwa sebagian besar perawat merasa puas dengan kualitas tidurnya. Temuan ini menjadi menarik karena kebanyakan penelitian menunjukan bahwa perawat dengan jam kerja shift memiliki gangguan tidur [15]. Kepuasan perawat shift akan kualitas tidur mereka bisa disebabkan persepsi subjektif perawat yang mempersepsikan kualitas tidur mereka baik karena mereka cukup efektif memanfaatkan waktu tidur yang mereka miliki [16]. Selain itu dengan karakteristik partisipan yang sudah bekerja minimal 3 bulan diduga membuat perawat sudah bisa menyesuaikan diri untuk memanfaatkan waktu tidur yang mereka miliki dengan efektif.

Waktu luang untuk rekreasi dan bersenang - senang merupakan salah satu aspek yang penting dalam meningkatkan kualitas hidup[17]. Hasil penelitian ini menunjukan hasil yang menarik pada persepsi perawat akan waktu luang yaitu sebagian besar perawat merasa bahwa mereka kurang memiliki waktu untuk rekreasi atau bersenang - senang. Jam kerja shift membuat perawat memiliki pola hidup yang tidak teratur sehingga menyulitkan mereka untuk memiliki waktu untuk berekreasi. Selain itu, perawat dengan jam kerja shift berada pada Poli rawat inap, UGD, dan ICU. Bagian tersebut mengharuskan perawat untuk selalu waspada memonitor pasien dan terkadang mengharuskan mereka bekerja lebih lama dari shift yang seharusnya. Sehingga peneliti berkesimpulan perawat yang bekerja secara shift sulit untuk memiliki waktu untuk rekreasi dan bersenang - senang.

Profesi perawat merupakan salah satu profesi yang penting dan menjadi tulang punggung layanan kesehatan. Secara umum perawat yang merasa puas dengan pekerjaan yang ia miliki dan berhasil meraih pencapaian pribadi menunjukan kepuasan terhadap hidup yang ia jalani[18]. Kepuasan perawat dengan pekerjaan terkait erat dengan kepuasan akan pendapatan dan relasi sosial mereka dengan rekan kerja atau teman [19]. Hasil penelitian ini menunjukan perawat dengan jam kerja shift merasa hidupnya berarti dan dapat menikmati hidupnya. Selain itu, sebagian besar perawat dengan jam kerja shift merasa puas dengan pendapatan yang mereka dapatkan. Kepuasan akan pekerjaan yang mereka lakukan dalam merawat pasien yang tidak diteliti dalam penelitian ini dan juga kepuasan akan pendapatan yang mereka dapatkan merupakan faktor yang meningkatkan keberartian hidup yang dimiliki perawat dengan jam kerja shift. 
Perawat dengan jam kerja shift dalam penelitian ini menunjukan pandangan yang positif terhadap diri mereka secara umum dan juga penampilan mereka. Hal ini bisa dijelaskan dari status pendidikan perawat yang menjadi responden penelitian ini yaitu sebagian besar perawat dengan jam kerja shift merupakan lulusan sarjana. Hasil ini sesuai dengan penelitian sebelumnya yang menyatakan bahwa semakin tinggi status pendidikan seorang perawat maka akan semakin tinggi self-esteem yang mereka miliki[20].

Hal menarik yang ditemukan dari domain psikologis adalah perawat dengan jam kerja shift memandang dirinya terkadang memiliki perasaan negatif seperti kesepian, putus asa, cemas dan depresi. Perawat dengan jam kerja shift berada pada poli yang berhubungan dengan pasien gawat atau dalam keadaan kritis seperti poli ICU dan IGD. Sehingga terkadang mereka merasakan perasaan gagal dan putus asa ketika gagal menyelamatkan pasien [19]. Terus menerus terpapar keadaan darurat pasien dan melihat pasien dalam keadaan hampir meninggal, ditambah lagi dengan jam kerja shift yang bisa mempengaruhi relasi mereka dengan keluarga pada akhirnya membuat mereka merasakan perasaan negatif.

\section{Perbandingan kualitas hidup perawat shift dan non-shift}

Analisa data yang dilakukan dengan membandingkan keempat domain kualitas hidup menunjukan terdapat perbedaan antara domain kualitas hidup perawat dengan jam kerja shift dan jam kerja nonshift. Domain yang memiliki perbedaan signifikan adalah domain fisik dan lingkungan. Jika dilihat dari rata - rata skornya, domain fisik dan domain lingkungan dari perawat dengan jam kerja shift lebih kecil dibandingkan dengan perawat dengan jam kerja non-shift.

Jika dilihat dari domain fisik, perawat dengan jam kerja shift melihat dirinya mengalami gangguan fisik yang mempengaruhi kehidupannya sehari - hari. Sedangkan perawat dengan jam kerja nonshift melihat dirinya jarang memiliki gangguan fisik. Jam kerja shift telah dibuktikan memberikan dampak yang buruk bagi kesehatan dan menyebabkan penyakit seperti kanker dan gangguan pencernaan dibandingkan dengan jam kerja non-shift $[5,8]$. Oleh karena itu terlihat adanya perbedaan kualitan hidup pada domain fisik perawat dengan jam kerja shift dan non-shift.

Pada domain lingkungan, hal ini kemungkinan disebabkan karena perawat dengan jam kerja shift merasa bahwa mereka kurang memiliki waktu luang untuk untuk sekedar melakukan rekreasi dan bersenang - senang. Sedangkan kecukupan waktu luang yang dimiliki individu untuk melakukan aktifitas fisik seperti olahraga memiliki pengaruh terhadap kualitas hidup perawat [21].

Perbedaan yang signifikan juga ditemukan pada bagaimana perawat dengan jam kerja shift dan jam kerja non-shift melihat kesehatan yang mereka miliki secara umum. Perbedaan pandangan akan kesehatan secara umum ini diduga berkaitan dengan bagaimana perawat melihat adanya gangguan fisik yang mereka alami. Gangguan fisik yang perawat dengan jam kerja shift alami pada akhirnya mengganggu aktifitas baik dalam pekerjaan maupun dalam kehidupan seharai - hari.

Terdapat limitasi dalam penelitian ini yaitu jumlah partisipan yang tidak seimbang antara kelompok perawat shift dan perawat non-shift. Selain itu penelitian ini hanya mendeskripsikan kualitas hidup perawat berdasarkan kuisioner WHOQOL-BREF sehingga perlu eksplorasi lebih jauh terkait alasan responden dalam menjawab pertanyaan - pertanyaan tersebut. Hal ini perlu dilakukan agar bisa menjawab dengan lebih dalam mengenai perbedaan signifikan antara perawat dengan jam kerja shift dan jam kerja non-shift. 


\section{SIMPULAN}

Secara umum penelitian ini memberikan informasi perawat dengan jam kerja shift memiliki nilai rata - rata kualitas hidup yang menurun dengan domain paling rendah adalah domain fisik. Sedangkan domain dengan nilai rata - rata paling tinggi adalah domain psikologis. Perbandingan dengan perawat dengan jam kerja non-shift juga dapat memperdalam temuan dengan memperlihat adanya perbedaan signifikan antara domain fisik dan lingkungan dari kualitas hidup perawat shift dan non-shift. Selain itu, berdasarkan rata - rata setiap domain ditemukan bahwa perawat dengan jam kerja shift memiliki skor rata - rata yang lebih rendah dibandingkan perawat nonshift.

Penelitian ini diharapkan dapat menjadi masukan bagi institusi rumah sakit untuk memperhatian kualitas hidup dari perawat yang memiliki jam kerja shift. Selain itu penelitian ini juga membuka peluang untuk meneliti lebih jauh mengenai pengaruh shift kerja terhadap kualitas hidup perawat dengan jumlah sampel yang lebih besar. Terakhir penelitian ini diharapkan bisa digunakan sebagai pembanding bagi penelitian - penelitian sejenis.

\section{UCAPAN TERIMAKASIH}

Ucapan terimakasih kami sampaikan kepada Dr. Fitri Ariyanti Abidin yang memberikan masukan pada penulisan jurnal ini, serta perawat representatif yang membantu dalam pengumpulan data penelitian. Tidak lupa kami mengucapkan terimakasih kepada seluruh partisipan yang bersedia berpartisipasi dalam penelitian ini.

\section{REFERENSI}

[1] Kabeel A, Eisa S. Relationship between job satisfaction and professional identity among psychiatric nurses. Egypt Nurs J 2017;14:9. https://doi.org/10.4103/2090-6021.206939.

[2] Gerber L. Understanding the nurse's role as a patient advocate. Nursing2021 2018;48.
[3] Kemenkes R. Infodatin Perawat 2017.Pdf 2017:1-12.

[4] Sun Q, Ji X, Zhou W, Liu J. Sleep problems in shift nurses: A brief review and recommendations at both individual and institutional levels. J Nurs Manag 2019;27:10-8. https://doi.org/10.1111/jonm.12656.

[5] Books C, Coody LC, Kauffman R, Abraham S. Night Shift Work and Its Health Effects on Nurses. Health Care Manag (Frederick) 2020;39.

[6] Vitale SA, Varrone-Ganesh J, Vu M. Nurses working the night shift: Impact on home, family and social life. J Nurs Educ Pract 2015;5. https://doi.org/10.5430/jnep.v5n10p70.

[7] Dai C, Qiu H, Huang Q, Hu P, Hong X, Tu J, et al. The effect of night shift on sleep quality and depressive symptoms among Chinese nurses. Neuropsychiatr Dis Treat 2019;15:435-40. https://doi.org/10.2147/NDT.S190689.

[8] Ibrahim Al Ameri MH. Night Shift and its Impact upon the Quality of Life of Nurses Working at the Teaching Hospitals of the Medical City Complex in Baghdad City, Iraq. J Nurs Care 2017;06:6-10. https://doi.org/10.4172/21671168.1000414 .

[9] The WHOQOL GROUP. Development of the World Health Organization WHOQOL-BREF quality of life assessment. Psychol Med 1998;28:551-8. https://doi.org/10.1017/s003329179800666 7.

[10] Delmas P, O’Reilly L, Cara C, Brousseau S, Weidmann J, Roulet-Schwab D, et al. Effects on nurses' quality of working life and on patients' quality of life of an educational intervention to strengthen humanistic practice among hemodialysis nurses in Switzerland: A protocol for a mixed-methods cluster randomized controlled trial. BMC Nurs 2018;17:1-11. https://doi.org/10.1186/s12912-018-0320-0.

[11] Ersanti ER, Ny V, Bulan R, Sitanggang YF, Hutasoit EO, Keperawatan MF, et al. Gambaran kualitas hidup profesional pada perawat di satu rumah sakit swasta indonesia bagian barat. Nurs Curr 2018;6:29-37.

[12] Ch Salim O, Sudharma NI, Kusumaratna RK, Hidayat A. Validity and reliability of World Health Organization Quality of Life-BREF to assess the quality of life in the elderly 2007;26:27-38.

[13] Purba FD, Hunfeld JAM, Iskandarsyah A, Fitriana S, Sadarjoen SS, Passchier J, et al. Quality of life of the Indonesian general population: Test-retest reliability and population norms of the EQ-5D-5L and 2018:1- 
20.

[14] WHO. WHOQOL User Manual. L 2012:1-19.

[15] Heckman CJ, Kloss JD, Feskanich D, Culnan E, Schernhammer ES. Associations among rotating night shift work, sleep and skin cancer in Nurses\&\#039; Health Study II participants. Occup Environ Med 2017;74:169 LP - 175. https://doi.org/10.1136/oemed-2016103783.

[16] Safitrie A, Ardani MH. Studi Komparatif Kualitas Tidur Perawat Shift dan Non Shift di Unit Rawat Inap dan Unit Rawat Jalan. Pros Konf Nas PPNI Jawa Teng 2013:17-23.

[17] Rogers SN, Travers A, Lowe D, Levy AR, Midgely AW. Importance of activity and recreation for the quality of life of patients treated for cancer of the head and neck. Br J Oral Maxillofac Surg 2019;57:125-34.

https://doi.org/10.1016/j.bjoms.2018.10.001.

[18] Mafini C, Dlodlo N. The relationship between extrinsic motivation, job satisfaction and life satisfaction amongst employees in a public organisation. SA J Ind Psychol 2014;40:1-13. https://doi.org/10.4102/sajip.v40i1.1166.

[19] Liu H, Zhang X, Chang R, Wang W. A research regarding the relationship among intensive care nurses' self-esteem, job satisfaction and subjective well-being. Int J Nurs Sci 2017;4:291-5.

https://doi.org/10.1016/j.ijnss.2017.06.008.

[20] Sabanciogullari S, Dogan S. Professional selfconcept in nurses and related factors: A sample from turkey. Int J Caring Serv 2017;10:167684.

[21] Peleias M, Tempski P, Paro HBMS, Perotta B, Mayer FB, Enns SC, et al. Leisure time physical activity and quality of life in medical students: results from a multicentre study. BMJ Open Sport \&amp;Amp; Exerc Med 2017;3:e000213. https://doi.org/10.1136/bmjsem-2016000213. 